\title{
Identification and Antibiotic Resistance Profile of Uropathogenic Bacteria from Sexually Active Women with Bacterial Vaginosis
}

\author{
Chinedum Taahie Oparaugo ${ }^{1,2^{*}}$, Bamidele Abiodun Iwalokun ${ }^{2,3,4}$, Adesegun Abiola Adesesan ${ }^{5}$, \\ Idowu Olaide Edu-Muyideen', Abimbola Modupe Adedeji6, Oliver Chukwujekwu Ezechi' \\ Mopelola Anotu Deji-Agboola²
}

\author{
${ }^{1}$ Biochemistry \& Nutrition Department, Nigerian Institute of Medical Research, Lagos, Nigeria \\ ${ }^{2}$ Department of Medical Microbiology \& Parasitology, Olabisi Onabanjo University, Ago-Iwoye, Nigeria \\ ${ }^{3}$ Molecular Biology \& Biotechnology Department, Nigerian Institute of Medical Research, Lagos, Nigeria \\ ${ }^{4}$ Central Research Laboratory, Nigerian Institute of Medical Research, Lagos, Nigeria \\ ${ }^{5}$ Microbiology Department, Nigerian Institute of Medical Research, Lagos, Nigeria \\ ${ }^{6}$ Monitoring \& Evaluation Unit, Nigerian Institute of Medical Research, Lagos, Nigeria \\ ${ }^{7}$ Clinical Science Department, Nigerian Institute of Medical Research, Lagos, Nigeria \\ Email: *ctoparaugo@yahoo.com
}

How to cite this paper: Oparaugo, C.T., Iwalokun, B.A., Adesesan, A.A., EduMuyideen, I.O., Adedeji, A.M., Ezechi, O.C. and Deji-Agboola, M.A. (2021) Identification and Antibiotic Resistance Profile of Uropathogenic Bacteria from Sexually Active Women with Bacterial Vaginosis. Journal of Biosciences and Medicines, 9, 52-67. https://doi.org/10.4236/jbm.2021.911006

Received: August 4, 2021

Accepted: November 14, 2021

Published: November 17, 2021

Copyright $\odot 2021$ by author(s) and Scientific Research Publishing Inc. This work is licensed under the Creative Commons Attribution International License (CC BY 4.0).

http://creativecommons.org/licenses/by/4.0/ (c) (i) Open Access

\begin{abstract}
Background: Urinary tract infections (UTIs) in women with bacterial vaginosis (BV) continue to pose tremendous health concerns and require appropriate use of antibiotics for effective case management. This study determined the prevalence, etiology and antibiotic resistance profile of uropathogenic bacteria isolated from sexually active women with BV in Lagos Nigeria. Method: A total of 258 sexually active women presenting with gynaecological complaints at the maternal and child unit of twenty Primary Health Care Centres in Lagos Nigeria from May 2017 to March 2018 were consecutively enrolled with consent. Bacterial vaginosis was diagnosed based on Amsel criteria. Midstream urine samples were collected aseptically, analyzed for bacterial pathogens and antibiotic susceptibility using standard microbiological methods. Results: BV was diagnosed in 184 (71.3\%) with $69.2 \%$ also having UTI. Ninety four (36.4\%) had UTI predominantly caused by Gram negative bacteria (96.8\%). The organisms isolated were Escherichia coli 79 (84.0\%), Klebsiella pneumoniae 5 (5.3\%), Pseudomonas aeruginosa 4 (4.3\%), Proteus mirabilis 3 (3.2\%) and Staphylococcus saprophyticus 3 (3.2\%). The pathogens elicited high resistance $(66.7 \%-100 \%)$ to tetracycline, amoxicillin-clavulanic acid, nitrofurantoin and cephalosporins, and moderate resistance $(50 \%)$ to ofloxacin by $P$. aeruginosa strains. The isolates were susceptible $(100 \%)$ to piperacillin-tazobactam and meropenem. Multi-drug resistance (MDR) was
\end{abstract}


observed among $97.8 \%$ of the bacteria isolated. Conclusion: Findings from this study indicate high occurrence of UTI caused by MDR pathogens among sexually active women with BV with emerging evidence of poor clinical utility of nitrofurantoin and other commonly used first-line antibiotics against UTI. Further studies on non-bacterial aetiology of BV, molecular characterization of $S$. saprophyticus and Gram Negative Bacteria UTI are recommended.

\section{Keywords}

Urinary Pathogens, Antibiotics Susceptibility, Bacterial Vaginosis, Women

\section{Introduction}

Bacterial vaginosis (BV) is the most common vaginal infection found in women of reproductive age and is estimated to occur in $5 \%$ to $70 \%$ of women [1] [2]. It is the commonest cause of unpleasant vaginal odour and discharge in women of reproductive age [3] [4]. It increases the risk of acquiring Human Immunodeficiency Virus and other sexually transmitted infections such as gonorrhoea, trichomoniasis, miscarriage, preterm labour, preterm delivery and postpartum complications such as endometritis and wound infections in pregnant women [5] [6]. BV is caused by a reduction in hydrogen peroxide-producing strains of lactobacilli in the vaginal flora. This leads to an elevated vaginal $\mathrm{pH}$ and increased levels of proteolytic enzymes (e.g., sialidase), organic acids, and volatile amines. This change in $\mathrm{pH}$ allows an overgrowth of multiple types of anaerobic, mycoplasmic, and Gram-negative bacteria. Women with a dominant population of vaginal lactobacilli are at a lower risk of UTI compared to women with more diverse microbiota, consisting of Gram negative anaerobes, Actinobacteria, and other Firmicutes. Also, women with BV have 2.2- to 13.7-fold increased risk of UTI [7] [8] [9].

Urinary tract infections (UTIs) are among the most commonly encountered bacterial infections in primary care and also represent the most common antibiotic-resistant infections in primary care [10] [11] leading to repeat consultations and problems for clinicians in selecting the right treatments. Globally, there are about 150 million individuals who are diagnosed with UTI [12]. UTIs have been associated with cystitis, pyelonephritis with sepsis, pre-term birth [13] [14] [15]. Women are more susceptible to UTI than men [16] [17] due to short urethra, absence of prostatic secretion, pregnancy and ease of contamination of the urinary tract with faecal flora [18]. Escherichia coli is the most prevalent uropathogen in patient with UTI, both in the community and hospitals [19] [20] [21]. However, other bacterial uropathogens implicated in UTI in women include $K$. pneumoniae, P. aeruginosa, Proteus spp. [22] [23] [24]. Of great concern is the recurrence of UTI among sexually active women despite treatment [25] [26]. This recurrence has been linked to co-infection caused by BV [27] [28] [29] [30] [31]. 
Antibiotics are considered the most effective method of treatment for bacterial infections but their indiscriminate, prolonged, empirical or incorrect usage has contributed greatly to the development of resistant strains [32] [33]. Resistance rate of uropathogens to commonly prescribed antibiotics has increased globally [34]. The multiple aetiologic agents, rising resistance to antibiotics, limiting treatment option can result in treatment failures and increased cost of health care [35]. There is limited data on the co-occurrence of UTI and BV among sexually active women in Nigeria. This study was carried out to determine the prevalence, antibiotic resistance of urinary tract pathogens among sexually active women with bacterial vaginosis. The information obtained in this study will be used for effective management of UTI among this group of women.

\section{Materials and Methods}

\subsection{Study Design}

This is a cross sectional study carried out from May 2017 to March 2018 among 258 sexually active women, aged 18 to 49 years that presented with gynaecological complaints at twenty flagship Primary Health Care centres in each of the 20 local government areas of Lagos State. This study involved BV screening, collection of urine samples, urinary culture, identification of uropathogens and antibiotic susceptibility testing.

\subsection{Ethical Approval and Informed Consent}

The study was approved by Nigerian Institute of Medical Research Institutional Review Board (IRB/15/306) and permission was obtained from Lagos State Primary Health Care Board. Random sampling was used in selection of participants and the patients were enrolled by convenience. Women of child bearing age from 18 to 49 years who engaged in regular heterosexual sex and had not taken antibiotics in the last one month were included in the study. Written informed consent was given by all participants. A pretested structured questionnaire was used to obtain socio-demographic data and reproductive history of sexually transmitted infections. Symptoms were extracted from case record forms of the participants.

\subsection{Sample Collection, Culture and Identification}

One High Vaginal Swab (HVS) was collected with sterile swab stick using sterile disposable speculum. Participants were given well-labelled sterile universal containers to collect 5 - $10 \mathrm{ml}$ of mid-stream urine. The specimens were transported to Clinical Diagnostic Laboratory Nigerian Institute of Medical Research for processing. Wet preparations from HVS samples were prepared in physiological saline and examined by light microscopy $(\times 10, \times 40$ objectives $)$. Amsel criteria were used for the diagnosis of BV. At least three of the four criteria were considered positive-presence of clue cells in wet mount (epithelial cells that appear to be coated in bacteria), vaginal $\mathrm{pH}>4.5$, release of a fishy odour on addition of 
$10 \%$ potassium hydroxide (positive "whiff" test) and a thin homogenous discharge. The urine specimens were cultured on MacConkey, Cysteine Lactose Electrolyte Deficient and Blood agar using standard sterile bacteriological loop $(0.01 \mathrm{ml})$. The plates were incubated at $37^{\circ} \mathrm{C}$ for 24 hours. Colonies were counted and UTI was diagnosed based on significant colony count of $\geq 10^{5} \mathrm{CFU} / \mathrm{ml}$ for the organisms.

Gram staining technique was used to differentiate the isolates into Gram-positive and Gram-negative by observing whether they were blue-black or red-stained, respectively [36]. Gram-positive isolates were cultured on mannitol salt agar (MSA); colonies that did not ferment mannitol (pink colonies), did not exhibit coagulase, deoxyribonuclease (DNase) activity and were resistant to novobiocin were considered to be $S$. saprophyticus. The Gram-negative isolates were characterized using standard biochemical tests which include oxidase, kligler iron agar (KIA), citrate utilization, indole and urease [37].

\subsection{Antibiotic Susceptibility Test}

Antibiotic susceptibility testing was conducted on Muller Hinton agar using a standard disc diffusion method according to CLSI guidelines [38]. The antibiotic discs used for tests were Amoxicillin-clavulanic acid (30 $\mu \mathrm{g})$, Nitrofurantoin (300 $\mu \mathrm{g})$, Gentamicin $(10 \mu \mathrm{g})$, Ofloxacin $(5 \mu \mathrm{g})$, Ceftazidime (30 $\mu \mathrm{g})$, Tetracycline (30 $\mu \mathrm{g})$, Cefuroxime $(30 \mu \mathrm{g})$, Cefixime $(5 \mu \mathrm{g})$, Erythromycin $(5 \mu \mathrm{g})$, and Cloxacillin $(5 \mu \mathrm{g})$, Vancomycin $(30 \mu \mathrm{g})$, Piperacillin-Tazobactam (110 $\mu \mathrm{g})$, Meropenem (10 $\mu \mathrm{g})$. E. coli ATCC 25922 and Staph aureus ATCC 25923 were used as control.

\subsection{Statistical Analysis}

Data from questionnaire and laboratory investigation was analyzed using SPSS version 23. Descriptive statistics was used to summarize the data. Chi-square was used to assess differences in the proportions of BV positive and negative patients.

\section{Results}

The sociodemographic characteristics and reproductive history of the sexually active women who participated in the study are summarized in Table 1. More than seventy percent $(76.2 \%)$ of the women in $40-49$ years age group had BV followed by $73.8 \%$ and $72.4 \%$ from $20-29$ and $30-39$ years age group respectively. Majority (67.4\%) of the women were aged 30 - 49 years, civil servants (42.6\%), lived in the urban area (82.6\%), had low income (58.1\%), completed tertiary education (56.6\%) and had more than one life time sexual partner (66.7\%). Further analysis showed that 108 (41.9\%) of the women had first sexual activity at age $21-25$ years. There was significant association of BV with sexual debut less than 10 years $(\mathrm{p}=0.02)$. Only $63(24.4 \%)$ of the participants were pregnant at enrolment into the study and $38(60.3 \%)$ of them had BV compared to $25(39.7 \%)$ without $\mathrm{BV}(\mathrm{p}=0.013)$. Majority $(67.4 \%)$ had vaginal delivery of 
Table 1. Sociodemographic characteristics and reproductive history of sexually active women with and without bacterial vaginosis.

\begin{tabular}{|c|c|c|c|c|}
\hline \multirow{2}{*}{ Variables } & \multirow{2}{*}{$\begin{array}{l}\text { Number of } \\
\text { Participants }\end{array}$} & \multicolumn{2}{|c|}{ Bacterial vaginosis } & \multirow{2}{*}{$\begin{array}{c}\text { Chi square test } \\
\text { P value }\end{array}$} \\
\hline & & Pos n (\%) & Neg n (\%) & \\
\hline \multicolumn{5}{|l|}{ Age group } \\
\hline$<19$ & $21(8.1)$ & $11(52.4)$ & $10(47.6)$ & \\
\hline $20-29$ & $42(16.3)$ & $31(73.8)$ & $11(26.2)$ & \\
\hline $30-39$ & $174(67.4)$ & $126(72.4)$ & $48(27.6)$ & \\
\hline $40-49$ & $21(8.1)$ & $16(76.2)$ & $5(23.8)$ & 0.245 \\
\hline \multicolumn{5}{|l|}{ Marital status } \\
\hline Single & $30(11.6)$ & $23(76.7)$ & $7(23.3)$ & \\
\hline Married & $228(88.4)$ & $161(70.6)$ & $67(29.4)$ & 0.491 \\
\hline \multicolumn{5}{|l|}{ Level of education } \\
\hline None & $4(1.6)$ & $4(100)$ & $0(0.0)$ & \\
\hline Primary & $2(0.8)$ & $2(100)$ & $0(0.0)$ & \\
\hline Secondary & $106(41.1)$ & $78(73.6)$ & $28(26.4)$ & 0.18 \\
\hline Tertiary & $146(56.6)$ & $100(68.5)$ & $46(31.5)$ & \\
\hline \multicolumn{5}{|l|}{ Religion } \\
\hline Christianity & $201(77.9)$ & $146(72.9)$ & $55(27.4)$ & \\
\hline Islam & $56(21.7)$ & $37(66.1)$ & $19(33.9)$ & 0.337 \\
\hline \multicolumn{5}{|l|}{ Occupation } \\
\hline Trader & $64(24.8)$ & $51(79.7)$ & $13(20.3)$ & \\
\hline Civil servant & $110(42.6)$ & $80(72.7)$ & $30(27.3)$ & 0.117 \\
\hline Self employed & $43(16.7)$ & $29(67.4)$ & $14(32.5)$ & \\
\hline Unemployed & $41(15.9)$ & $24(58.5)$ & $17(41.5)$ & \\
\hline \multicolumn{5}{|l|}{ Residence } \\
\hline Rural & $45(17.4)$ & $34(75.6)$ & $11(24.4)$ & \\
\hline Urban & $213(82.6)$ & $150(70.4)$ & $63(29.6)$ & 0.489 \\
\hline \multicolumn{5}{|l|}{ Monthly Income } \\
\hline No income & $21(8.1)$ & $14(66.7)$ & $7(33.3)$ & 0.792 \\
\hline Low $(<\$ 60)$ & $150(58.1)$ & $106(70.7)$ & $44(29.3)$ & \\
\hline Middle (\$60 - \$600) & $87(33.7)$ & $64(73.6)$ & $23(26.4)$ & \\
\hline \multicolumn{5}{|l|}{ Reproductive history } \\
\hline \multicolumn{5}{|l|}{ Pregnant } \\
\hline Never pregnant & $63(24.4)$ & $41(65.1)$ & $22(34.9)$ & 0.208 \\
\hline Pregnant before & $195(75.6)$ & $143(73.3)$ & $52(26.7)$ & \\
\hline
\end{tabular}




\section{Continued}

Pregnant now

Yes

No

Not sure

Life birth

None

$\geq 1$ life birth

$63(24.4)$

87 (33.7)

$38(60.3)$

25 (39.7)

0.013

87 (80.6)

21 (19.4)

$59(67.8) \quad 28(32.2)$

Method of child delivery

Caesarian section
Vaginal delivery

Temination of pregnancy

$\begin{array}{cccc}\text { Abortion } & 43(16.7) & 30(69.8) & 13(30.2) \\ \text { Miscarriage } & 22(8.5) & 20(90.9) & 2(9.1)\end{array}$

Number of life time sexual partners

$\begin{array}{ccccc}1 & 86(33.3) & 58(67.4) & 28(32.6) & \\ 2-5 & 172(66.7) & 126(73.3) & 46(26.7) & 0.33\end{array}$

Age at sexual debut

(years)

$\begin{array}{cccc}<10 & 1(0.4) & 1(100) & 0(0.0) \\ 11-15 & 21(8.1) & 19(90.4) & 2(9.5) \\ 16-20 & 85(32.9) & 55(64.7) & 30(35.3) \\ 21-25 & 108(41.9) & 72(66.7) & 36(33.3) \\ 26-30 & 43(16.7) & 37(86.0) & 6(14.0)\end{array}$

children and $73.6 \%$ of them had BV. More than sixteen percent $(16.7 \%)$ of the women terminated their pregnancy through abortion and $69.8 \%$ of them had BV. Only $21(8.1 \%)$ of the participants reported history of family planning using injectables and $14(66.7 \%)$ of them had BV. Pattern of the symptoms elicited by the women included vaginal discharge only (49.2\%), lower abdominal pain (8.9\%), vaginal itching (8.1\%), vaginal itching and discharge $(6.6 \%)$, foul odour from vagina $(5.8 \%)$, itching and lower abdominal pain $(3.9 \%)$.

Out of the 258 cultures performed, only 94 (36.4\%) had significant bacteriuria. Ninety-one (96.8\%) were Gram negative bacteria while 3 (3.2\%) were Gram positive bacteria. On the whole, the prevalence of UTI and BV was found to be 94 (36.4\%) and $184(71.3 \%)$ respectively. Almost seventy percent $(69.2 \%)$ of the women with BV had UTI. The uropathogenic bacteria isolated were $E$ coli (30.6\%), K. pneumoniae (1.8\%), P. aeruginosa (1.6\%), Proteus mirabilis $(1.2 \%)$ and S. saprophyticus (1.2\%). Further analysis showed that majority (58.5\%) of 
the women with BV and UTI had E. coli as the urinary pathogen while $25.5 \%$ had only $E$. coli (Figure 1). There was significant association between BV and $E$. coli $(\mathrm{p}=0.02)$. Also, $3.2 \%$ of the participants had $P$. aeruginosa and $\mathrm{BV}, 4.3 \%$ had $K$. pneumoniae and BV, $2.1 \%$ had $P$. mirabilis and BV while $1.1 \%$ of each of the women with $P$. aeruginosa, $K$. pneumoniae, $P$. mirabilis don't have BV. Only $1.1 \%$ had $S$. saprophyticus and BV while $2.1 \%$ had only $S$. saprophyticus.

Figure 2 shows the antibiotic resistance profile of the isolated uropathogenic bacteria. All isolates were $100 \%$ sensitive to piperacillin-tazobactam and meropenem. S. saprophyticus was $100 \%$ sensitive to vancomycin. Overall, the highest level of resistance was observed in amoxicillin-clavulanic acid (100\%) and cefuroxime (100\%) for Gram negative and erythromycin (100\%) for Gram positive bacteria. $P$. aeruginosa was $100 \%$ resistant to tetracycline, nitrofurantoin, cefixime and ceftazidime. $P$. mirabilis was $100 \%$ resistant to tetracycline and gentamicin while $K$. pneumoniae was $100 \%$ resistant to tetracycline only. E. coli isolates showed $98 \%$ resistance to cefixime followed by ceftazidime (94.9\%), tetracycline $(89.9 \%)$, gentamicin $(69.6 \%)$, nitrofurantoin $(45.6 \%)$ and ofloxacin (39.3\%) whereas $P$. aeruginosa showed 50\% resistance to ofloxacin and $75 \%$ (gentamicin). Eighty percent of $K$. pneumoniae isolates were resistant to cefixime, ceftazidime, gentamicin followed by $40 \%$ resistance to ofloxacin and gentamicin. $P$. mirabilis showed $33.3 \%$ resistant to ofloxacin, nitrofurantoin and $66.7 \%$ to cefixime, ceftazidime. S. saprophyticus, the only Gram positive bacteria

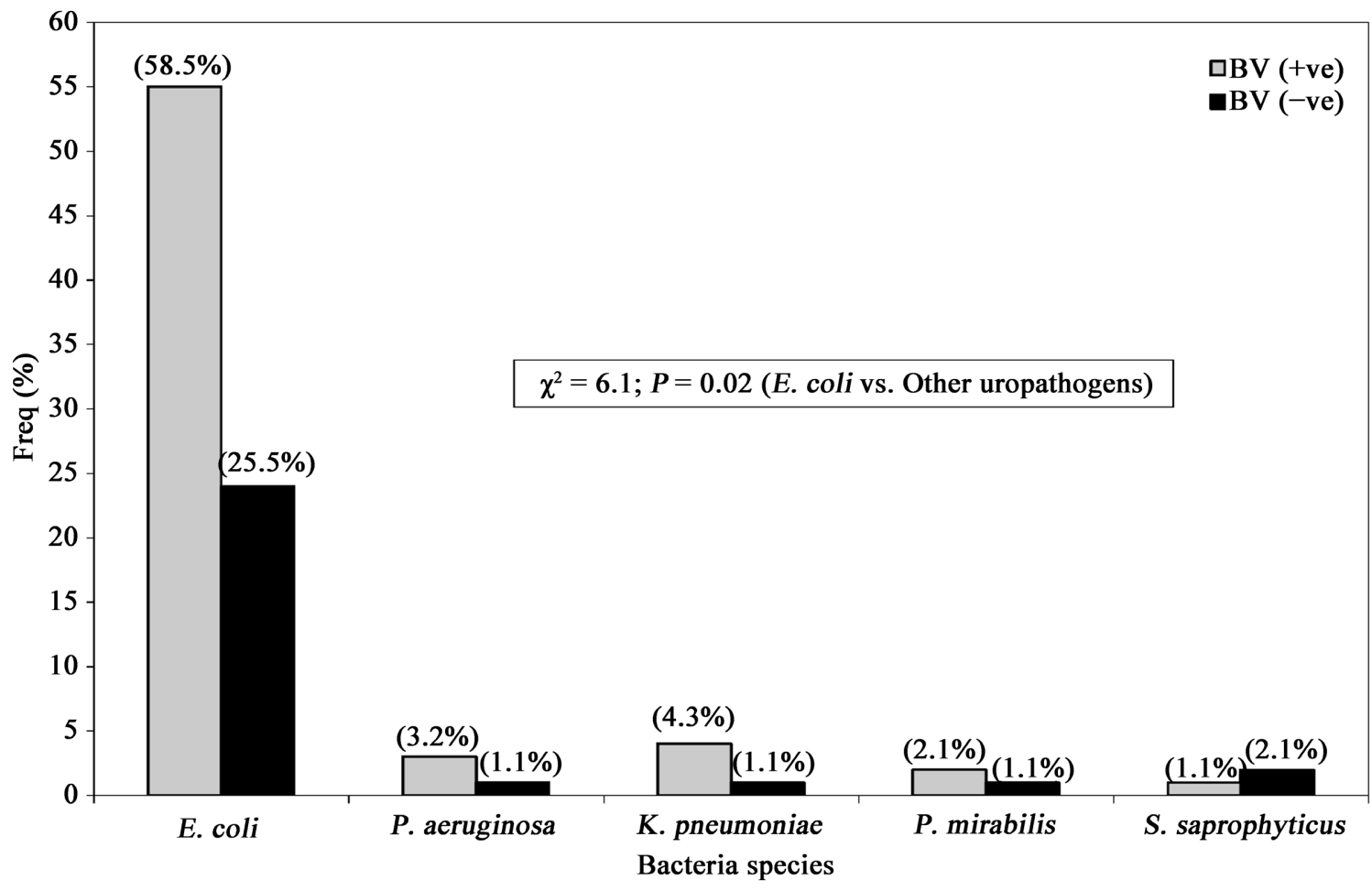

$\mathrm{BV}(+\mathrm{ve})=$ Bacterial vaginosis positive; $\mathrm{BV}(-\mathrm{ve})=$ Bacterial vaginosis negative. $\mathrm{P}<0.05$ was significant.

Figure 1. Distribution by species of the bacteriologic etiology of urinary tract infection among the sexually active women with and without bacterial vaginosis. 


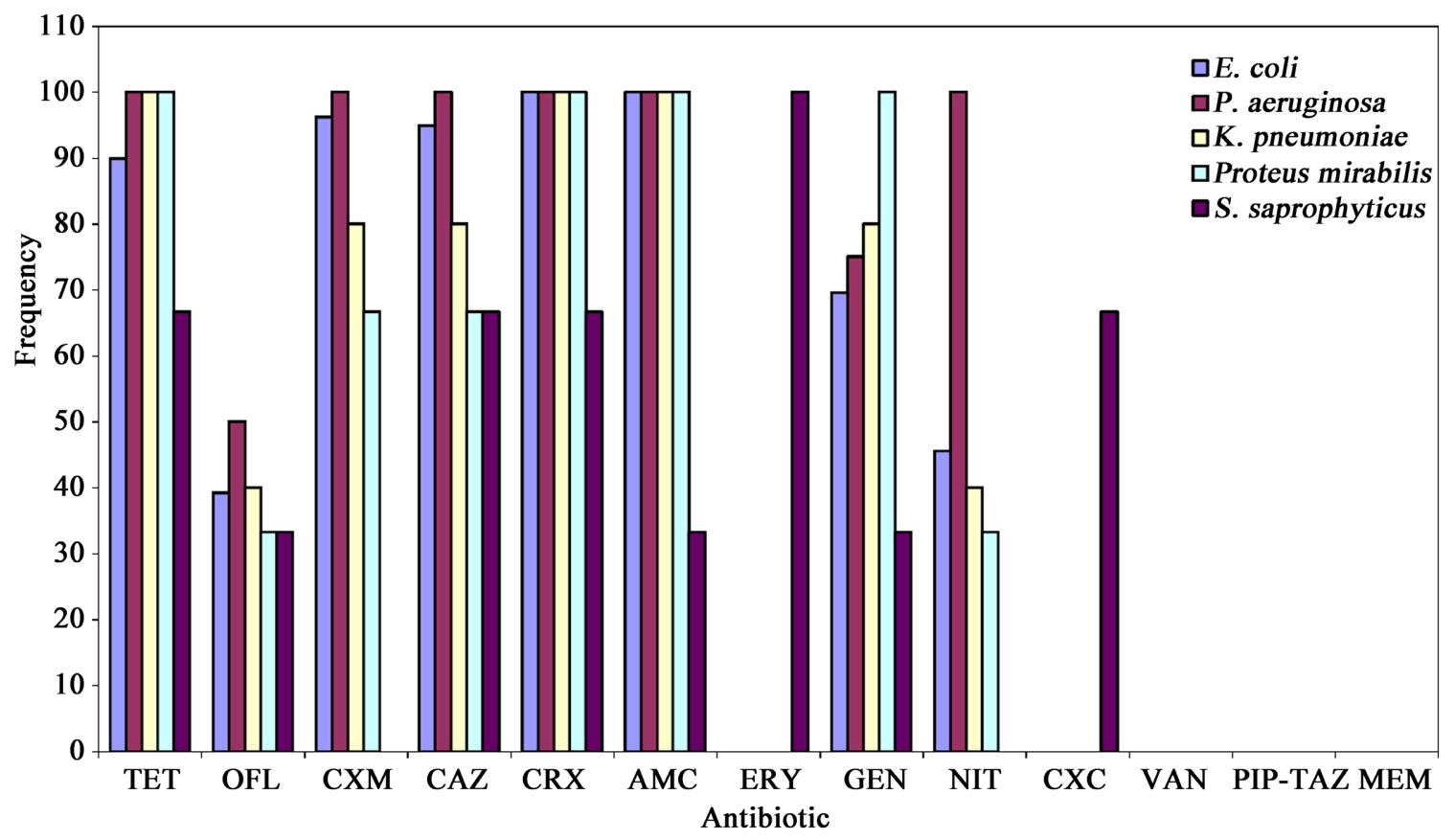

TET $=$ Tetracycline OFL $=$ Ofloxacin, $\mathrm{CXM}=$ Cefixim, $\mathrm{CRX}=$ Cefuroxim, $\mathrm{AMC}=$ Augmentin, $\mathrm{ERY}=$ Erythromycin, GEN = Gentamicin, NIT $=$ Nitrofuratioin, $\mathrm{CXC}=$ Cloxacillin, VAN =Vancomycin, PIP $-\mathrm{TAZ}=$ Piperacillin $=$ Tazobactam. MEM = Meropenem

Figure 2. Antibiotic resistance profile of the isolated uropathogenic bacterial strains.

isolated demonstrated $66.7 \%$ resistant to tetracycline, ceftazidime, cefuroxime, cloxacillin and $33.3 \%$ to ofloxacin, gentamicin, amoxicillin-clavulanic acid. Multi-drug resistance (MDR) was observed among $97.8 \%$ of the bacteria isolated.

\section{Discussion}

The occurrence of UTI in women with BV has been well reported. However, more data are needed with regard to incriminating pathogens and their antibiotic resistance profile among sexually active women in Nigeria. In this study, the prevalence of UTI among women with BV is $69.2 \%$. This prevalence is lower than the report (75\%) by Amatya et al. [31]. However, it is higher than the result by Gupta et al. (21.2\%) [39], Sumati and Saritha (42.27\%) [7], Lamichhane et al. (23.4\%) [40], Hillerbrand et al. (13.6\%) [9]. The disparity may be due to differences in study populations and number of sexual partners. Majority (73.3\%) of the women with multiple sex partners had BV, this may have increased the risk of UTI. BV provide polarization of pathogens due to reduction of vaginal lactobacilli and increase in $\mathrm{pH}$. Therefore, UTI screening should be integrated with $\mathrm{BV}$ screening especially in women with multiple sex partners.

The present study also confirmed high burden of BV among sexually active women in Nigeria as reported previously by Victor et al. [41], Awoniyi et al. [42]. BV was highest (76.2\%) in the age group $40-49$ years. However, Gupta et al. [39] and Lamichhane et al. [40] reported BV prevalence of 78.7\% and 80.6\% respectively in age group $21-30$ years. The greater infection prevalence in the 21 
- 30 years age group could be related to the fact that this is among the most reproductively active age and has the highest sexual exposure.

As a potential factor that could complicate the management of BV in sexually active Nigerian women, common risk factors identified were multiple sex partners and age at first sexual activity which has also been reported by Verstraelen et al. [43], Vodstrcil et al. [44] and Fethers et al. [45]. The study found out that all the women with primary or no education had BV. This finding agrees with what Ajayi et al. [46] reported that BV was more commonly found among those with little or no education. However, Bitew et al. [47] reported that BV was higher in women with primary and secondary education compared to illiterates. In accordance with our study, there is no significant association between BV and the number of abortions [47]. The present study revealed significant association of $\mathrm{BV}$ with pregnancy $(\mathrm{p}=0.013)$. BV is common problem in pregnant women and studies by Afolabi et al. [48], Das et al. [49], Kiran et al. [50], Isik et al. [51] showed BV to be a risk factor for adverse obstetric and gynaecological outcomes.

This study identified five different types of pathogen namely E. coli, $K$. pneumoniae, $P$. aeruginosa, $P$. mirabilis and $S$. saprophyticus. This is unlike previous studies by Bhavana et al. [52] and Gupta et al. [39] who found only E. coli, Klebsiella spp., Citrobacter spp., Providencia spp., P. aeruginosa, Acinetobacter baumannii, S. aureus, Enterococci, coagulase negative staphylococci (CONS) and E. coli, Klebsiella spp., Enterobacter spp., Staphylococcus spp. respectively. This shows that new pathogens are emerging as causes of UTI in BV and may vary from one region to another.

The antibiotic resistance pattern showed that the pathogens were resistant to most of the commonly used first-line antibiotics. This study shows that piperacillin-tazobactam, meropenem are effective antibiotics for UTI management in BV caused by Gram negative bacteria. Studies by Bhavana et al. [52] showed that E. coli was not sensitive to piperacillin-tazobactam. This may be due to differences in the use of the antibiotics. Vancomycin was found to be the effective antibiotics for managing UTI caused by $S$. saprophyticus in BV. Bhavana et al. [52] reported that CONS showed $100 \%$ sensitivity to vancomycin and cefixime.

Multi-drug resistance was observed among $97.8 \%$ of the bacteria isolated. Studies by Belete [53], Wabe et al. [54] and Onyango et al. [55] reported 80.4\%, $57.1 \%$ and $96 \%$ respectively. In another study, Gessese et al. reported MDR in all isolates [56]. The high prevalence of MDR seen in this study can be as a result of indiscriminate use of antibiotics. Also, bacteria can acquire resistance genes from plasmids and other transferred genetic material. Moreover, some bacteria like $E$. coli form biofilms on the mucosal lining of the bladder to resist antibiotic treatment and host immune response [57]. There is need for precautionary use of antibiotics while managing UTI in BV. UTI screening and antibiotic susceptibility test should be integrated among sexually active women. This will help to prevent maternal health outcomes.

In conclusion, there is a high level of resistance among UTI isolates in sexually active women with BV. Antibiotics stewardship and resistance surveillance 
should be conducted regularly. Counseling and education of patients on adherence to prescribed treatment, proper hygenic practices, and treatment of symptomatic sex partners, are critical for improving patient outcomes and preventing recurrence. Future research work should embark on molecular characterization of urinary pathogens from this group of women. Women with BV have UTI more than women without BV; therefore, BV screening should be conducted for women carrying out UTI test.

\section{Limitations of the Study}

1) The study was done in Primary Health Care centres only. The secondary, tertiary and private facilities were not taken into consideration. Therefore, the findings cannot be extrapolated to the general population.

2) The study was carried out in one state which is a representative of a geopolitical zone. The other five zones were not included so the results cannot be generalized for the whole country.

\section{Conflicts of Interest}

The authors declare no conflicts of interest regarding the publication of this paper.

\section{References}

[1] Janulaitiene, M., Paliulyte, V., Grinceviciene, S., Zakareviciene, J., Vladisauskiene, A., Marcinkute, A., et al. (2017) Prevalence and Distribution of Gardnerella vaginalis Subgroups in Women with and without Bacterial Vaginosis. BMC Infectious Diseases, 17, 394. https://doi.org/10.1186/s12879-017-2501-y

[2] Kenyon, C.R. and Osbak, K. (2014) Recent Progress in Understanding the Epidemiology of Bacterial Vaginosis. Current Opinion in Obstetrics and Gynecology, 26, 448-454. https://doi.org/10.1097/GCO.0000000000000112

[3] Brotman, R.M. (2011) Vaginal Microbiome and Sexually Transmitted Infections: An Epidemiologic Perspective. Journal of Clinical Investigation, 121, 4610-4617. https://doi.org/10.1172/JCI57172

[4] Marrazzo, J.M. (2011) Interpreting the Epidemiology and Natural History of Bacterial Vaginosis: Are We Still Confused. Anaerobe, 17, 186-190. https://doi.org/10.1016/j.anaerobe.2011.03.016

[5] Laxmi, U., Agrawal, S., Raghunandan, C., Randhawa, V.S. and Saili, A. (2012) Association of Bacterial Vaginosis with Adverse Fetomaternal Outcome in Women with Spontaneous Preterm Labor: A Prospective Cohort Study. The Journal of Maternal-Fetal \& Neonatal Medicine, 25, 64-67. https://doi.org/10.3109/14767058.2011.565390

[6] Brotman, R.M., Klebanoff, M.A., Nansel, T.R. and Schwebke, J.R. (2010) Bacterial Vaginosis Assessed by Gram Stain and Diminished Colonization Resistance to Incident Gonococcal, Chlamydial, and Trichomonal Genital Infection. The Journal of Infectious Diseases, 202, 1907-1915. https://doi.org/10.1086/657320

[7] Sumati, A.H. and Saritha, N.K. (2009) Association of Urinary Tract Infection in Women with Bacterial Vaginosis. Journal of Global Infectious Diseases, 1, 151-152. https://doi.org/10.4103/0974-777X.56254 
[8] Sharami, S.H., Afrakhteh, M. and Shakiba, M. (2007) Urinary Tract Infections in Pregnant Women with Bacterial Vaginosis. Journal of Obstetrics and Gynaecology, 27, 252-254. https://doi.org/10.1080/01443610701194846

[9] Hillebrand, L., Harmanli, O.H., Whiteman, V. and Khandelwal, M. (2002) Urinary Tract Infections in Pregnant Women with Bacterial Vaginosis. American Journal of Obstetrics \& Gynecology, 186, 916-917. https://doi.org/10.1067/mob.2002.123987

[10] Bryce, A., Hay, A.D., Lane, I.F., Thornton, H.V. and Wootton, M. (2016) Global Prevalence of Antibiotic Resistance in Paediatric Urinary Tract Infections Caused by Escherichia coli and Association with Routine Use of Antibiotics in Primary Care: Systematic Review and Meta-Analysis. BMJ, 352, i939.

https://doi.org/10.1136/bmj.i939

[11] Chin, T.L., MacGowan, A.P., Bowker, K.E., Elder, F., Beck, C.R. and McNulty, C. (2015) Prevalence of Antibiotic Resistance in Escherichia coli Isolated from Urine Samples Routinely Referred by General Practitioners in a Large Urban Centre in South-West England. Journal of Antimicrobial Chemotherapy, 70, 2167-2169. https://doi.org/10.1093/jac/dkv050

[12] Amiri, M., Lavasani, Z., Norouzirad, R., Najibpour, R., Mohamadpour, M., Nikpoor, A.R., et al. (2015) Prevalence of Urinary Tract Infection among Pregnant Women and Its Complications in Their New Born during the Birth in the Hospitals of Dezful City, Iran, 2012-2013. Iranian Red Crescent Medical Journal, 17, e26946. https://doi.org/10.5812/ircmj.26946

[13] Flores-Mireles, A.L., Walker, J.N., Caparon, M. and Hultgren, S.J. (2015) Urinary Tract Infections: Epidemiology, Mechanisms of Infection and Treatment Options. Nature Reviews Microbiology, 13, 269-284. https://doi.org/10.1038/nrmicro3432

[14] Hooton, T.M. (2012) Clinical Practice. Uncomplicated Urinary Tract Infection. The New England Journal of Medicine, 366, 1028-1037.

https://doi.org/10.1056/NEJMcp1104429

[15] Hannan, T.J., Totsika, M., Mansfield, K.J., Moore, K.H., Schembri, M.A. and Hultgren, S.J. (2012) Host-Pathogen Check Points and Population Bottle Necks in Persistent and Intracellular Uropathogenic E. coli Bladder Infection. FEMS Microbiology Reviews, 36, 616-648. https://doi.org/10.1111/j.1574-6976.2012.00339.x

[16] Emiru, T., Beyene, G., Tsegaye, W. and Melaku, S. (2013) Associated Risk Factors of UTI among Pregnant Women at Felege Hiwot Referral Hospital, Bahir Dar. BMC Research Notes, 6, 292. https://doi.org/10.1186/1756-0500-6-292

[17] Alemu, A., Moges, F., Shiferaw, Y., Tafesse, K., Kassu, A., Anagaw, B., et al. (2012) Bacterial Profile and Drug Susceptibility Pattern of UTI in Pregnant Women at University of Gondar Teaching Hospital. Ethiopian Journal of Health Sciences, 25, 197. https://doi.org/10.1186/1756-0500-5-197

[18] Tazebew, D., Getenet, B., Selabat, M. and Wondewosen, T. (2012) Urinary Bacterial Profile and Antibiotic Susceptibility Pattern among Pregnant Women in North West Ethiopia. Ethiopian Journal of Health Sciences, 22, 121-128.

[19] Anejo-Okopi, A.J., Okwori, A.E.J., Eze, M.I., Onaji, A.I., Ali, M., Adekwu, A., et al. (2015) Prevalence and Antibiotic Resistance Pattern of Urinary Tract Bacterial Infections among Symptomatic Patients Attending University of Maiduguri Teaching Hospital, North East Nigeria. European Journal of Advanced Research in Biological and Life Sciences, 3, 31-41.

[20] Foxman, B. (2014) Urinary Tract Infection Syndromes: Occurrence, Recurrence, Bacteriology, Risk Factors, and Disease Burden. Infectious Disease Clinics of North America, 28, 1-13. https://doi.org/10.1016/j.idc.2013.09.003 
[21] Bano, K., Khan, J., Begum, H., Munir, S., Akbar, N., Ansari, J.A., et al. (2012) Patterns of Antibiotic Sensitivity of Bacterial Pathogens among Urinary Tract Infections (UTI) Patients in a Pakistani Population. African Journal of Microbiology Research, 6, 414-420. https://doi.org/10.5897/AJMR11.1171

[22] Sierra-Díaz, E., Hernández-Ríos, C.J. and Bravo-Cuellar, A. (2019) Antibiotic Resistance: Microbiological Profile of Urinary Tract Infections in Mexico. Cirugía $y$ Cirujanos, 87, 176-182. https://doi.org/10.24875/CIRU.18000494

[23] Kaduma, J., Seni, J., Chuma, C., Kirita, R., Mujuni, F., Mushi, M.F., et al. (2019) Urinary Tract Infections and Preeclampsia among Pregnant Women Attending Two Hospitals in Mwanza City, Tanzania: A 1:2 Matched Case-Control Study. BioMed Research International, 2019, Article ID: 3937812. https://doi.org/10.1155/2019/3937812

[24] Ekwedigwe, K.C., Sunday-Adeoye, I., Eliboh, M.O., Isikhuemen, M.E., Uro-Chukwu, H., Ezeonu, P., et al. (2018) Prevalence and Antimicrobial Susceptibility of Asymptomatic Bacteriuria among Women with Pelvic Organ Prolapse in Abakaliki, South-East Nigeria. BMC Women's Health, 18, 53. https://doi.org/10.1186/s12905-018-0545-9

[25] Arnold, J.J., Hehn, L.E. and Klein, D.A. (2016) Common Questions about Recurrent Urinary Tract Infections in Women. American Family Physician, 93, 560-569.

[26] Aydin, A., Ahmed, K., Zaman, I., Khan, M.S. and Dasgupta, P. (2015) Recurrent Urinary Tract Infections in Women. International Urogynecology Journal, 26, 795-804. https://doi.org/10.1007/s00192-014-2569-5

[27] Gilbert, N.M., O’Brien, V.P. and Lewis, A.L. (2017) Transient Microbiota Exposures Activate Dormant Escherichia coli Infection in the Bladder and Drive Severe Outcomes of Recurrent Disease. PLOS Pathogens, 13, e1006238. https://doi.org/10.1371/journal.ppat.1006238

[28] Gautam, R., Borgdorff, H., Jespers, V., Francis, S.C., Verhelst, R., Mwaura, M., et al. (2015) Correlates of the Molecular Vaginal Microbiota Composition of African Women. BMC Infectious Diseases, 15, 86. https://doi.org/10.1186/s12879-015-0831-1

[29] Balashov, S.V., Mordechai, E., Adelson, M.E. and Gygax, S.E. (2014) Identification, Quantification and Subtyping of Gardnerella vaginalis in Noncultured Clinical Vaginal Samples by Quantitative PCR. Journal of Medical Microbiology, 63, 162-175. https://doi.org/10.1099/jmm.0.066407-0

[30] Shipitsyna, E., Roos, A., Datcu, R., Hallen, A., Fredlund, H., Jensen, J.S., et al. (2013) Composition of the Vaginal Microbiota in Women of Reproductive Age-Sensitive and Specific Molecular Diagnosis of Bacterial Vaginosis Is Possible? PLoS ONE, 8 , e60670. https://doi.org/10.1371/journal.pone.0060670

[31] Amatya, R., Mandal, P., Tuladhar, H. and Karki, B. (2013) Urinary Tract Infection in Vaginitis: A Condition Often Overlooked. Nepal Medical College Journal, 15, 65-67.

[32] Llor, C. and Bjerrum, L. (2014) Antimicrobial Resistance: Risk Associated with Antibiotic Overuse and Initiatives to Reduce the Problem. Therapeutic Advances in Drug Safety, 5, 229-241. https://doi.org/10.1177/2042098614554919

[33] Laxminarayan, R., Duse, A., Wattal, C., Zaidi, A.K., Wertheim, H.F., Sumpradit, N., et al. (2013) Antibiotic Resistance: The Need for Global Solutions. The Lancet Infectious Diseases, 13, 1057-1098. https://doi.org/10.1016/S1473-3099(13)70318-9

[34] Kahlmeter, G. and Poulsen, H.O. (2012) Antimicrobial Susceptibility of Escherichia coli from Community-Acquired Urinary Tract Infections in Europe: The ECO 
SENS Study Revisited. International Journal of Antimicrobial Agents, 39, 45-51. https://doi.org/10.1016/j.ijantimicag.2011.09.013

[35] World Health Organization (2014) Antimicrobial Resistance. Global Report on Surveillance.

https://www.who.int/antimicrobial-resistance/publications/global-action-plan/en

[36] Ochei, J. and Kolhatkar, A. (2008) Medical Laboratory Science: Theory and Practice. Tata McGraw-Hill Publishing Company Limited, London, 473, 685.

[37] Cheesbrough, M. (2000) District Lab Practice in Tropical Countries Part 2. Biochemical Reactions of Some Enterobacteria and Other Enteric Organisms. Cambridge University Press, Cambridge, 159, 180.

[38] CLSI (2015) Performance Standards for Antimicrobial Disk Susceptibility Tests, Approved Standard. Twelfth Edition, Clinical and Laboratory Standards Institute, Wayne.

[39] Gupta, R.S., Bhargav, D. and Deep, J.P. (2021) Common Types of Vaginitis (Bacterial vaginosis, Vulvovaginal candidiasis, Trichomoniasis) and Their Association with Urinary Tract Infection among Women Visiting NMCTH, Birgunj. International Journal of Current Microbiology and Applied Sciences, 10, 996-1010. https://doi.org/10.20546/ijcmas.2021.1001.121

[40] Lamichhane, P., Joshi, D.R., Subedi, Y.P., Thapa, R., Acharya, G.P., Lamsal, A., et al. (2014) Study on Types of Vaginitis and Association between Bacterial Vaginosis and Urinary Tract Infection in Pregnant Women. International Journal of Biomedical and Advance Research, 5, 304-307.

[41] Victor, O., Emmanuel, K., Isreal, O., Ranyang, A. and Elizabeth, R. (2017) Prevalence Risk Factors and Diagnostic Methods of Bacterial Vaginosis: A Survey of Pregnant Women Attending Antenatal Clinic at Taraba State Specialist Hospital, North-East, Nigeria. Annals of Internal Medicine, 1, 1-9.

https://doi.org/10.24087/IAM.2017.1.11.380

[42] Awoniyi, A.O., Komolafe, O.I., Bifarin, O. and Olaniran, O. (2015) Bacterial Vaginosis among Pregnant Women Attending a Primary Health Care Center in lle-Ife, Nigeria. Global Advanced Research Journal of Medicine and Medical Sciences, 4, 57-60.

[43] Verstraelen, H., Verhelst, R., Vaneechoutte, M. and Temmer-man, M. (2010) The Epidemiology of Bacterial Vaginosis in Relation to Sexual Behaviour. BMC Infectious Diseases, 10, 81. https://doi.org/10.1186/1471-2334-10-81

[44] Vodstrcil, L.A., Hocking, J.S., Law, M., Walker, S., Tabrizi, S.N., Fairley, C.K. and Bradshaw, C.S. (2013) Hormonal Contraception Is Associated with a Reduced Risk of Bacterial Vaginosis: A Systematic Review and Meta-Analysis. PLoS ONE, 8, e73055. https://doi.org/10.1371/journal.pone.0073055

[45] Fethers, K., Twin, J., Fairley, C.K., Fowkes, F.J.I., Garland, S.M., Fehler, G., et al. (2012) Bacterial Vaginosis Candidate Bacteria: Associations with BV and Behavioural Practices in Sexually-Experienced and Inexperienced Women. PLoS ONE, 7, e30633. https://doi.org/10.1371/journal.pone.0030633

[46] Ajayi, V.D., Sadauki, H.M., Randawa, A. and Afolabi, B.M. (2016) Bacterial Vaginosis Is a Common Vaginal Infection among First-Time Antenatal Clinic Attendees: Evidence from a Tertiary Health Facility in North-West Nigeria. Journal of Prevention \& Infection Control, 2, 14. https://doi.org/10.21767/2471-9668.100023

[47] Bitew, A., Abebaw, Y., Bekele, D. and Mihret, A. (2017) Prevalence of Bacterial Vaginosis and Associated Risk Factors among Women Complaining of Genital Tract Infection. International Journal of Microbiology, 2017, Article ID: 4919404. 
https://doi.org/10.1155/2017/4919404

[48] Afolabi, B.B., Olusanjo, E.M. and Oyinlola, O.O. (2016) Bacterial Vaginosis and Pregnancy Outcome in Lagos, Nigeria. Open Forum Infectious Diseases, 3, ofw030. https://doi.org/10.1093/ofid/ofw030

[49] Das, T.R., Fatema, K., Chowdhury, S., Noor, F., Ara, R., Chakma, B., et al. (2017) Association of Bacterial Vaginosis with Preterm Delivery. Journal of Bangladesh College of Physicians and Surgeons, 34, 188-192. https://doi.org/10.3329/jbcps.v34i4.32408

[50] Kiran, C.K., Kandati, J. and Ponugoti, M. (2017) Prevalence of Bacterial Vaginosis in Preterm and Term Labour: A One Year Study. International Journal of Reproduction, Contraception, Obstetrics and Gynecology, 6, 2292-2296.

https://doi.org/10.18203/2320-1770.ijrcog20172072

[51] Işik, G., Demirezen, S., Dönmez, G.H. and Beksaç, S.M. (2016) Bacterial Vaginosis in Association with Spontaneous Abortion and Recurrent Pregnancy Losses. Journal of Cytology, 33, 135-140. https://doi.org/10.4103/0970-9371.188050

[52] Bhavana, A.M., Kumari, P.H.P., Mohan, N., Chandrasekhar, V., Vijayalakshmi, P. and Manasa, R.V. (2019) Bacterial Vaginosis and Antibacterial Susceptibility Pattern of Asymptomatic Urinary Tract Infection in Pregnant Women at a Tertiary Care Hospital, Visakhaptn, India. Iranian Journal of Microbiology, 11, 488-495. https://doi.org/10.18502/ijm.v11i6.2220

[53] Belete, M.A. (2020) Bacterial Profile and ESBL Screening of Urinary Tract Infection Among Asymptomatic and Symptomatic Pregnant Women Attending Antenatal Care of Northeastern Ethiopia Region. Infection and Drug Resistance, 13, 2579-2592. https://doi.org/10.2147/IDR.S258379

[54] Wabe, Y.A., Reda, D.Y., Abreham, E.T., Gobene, D.B. and Ali, M.M. (2020) Prevalence of Asymptomatic Bacteriuria, Associated Factors and Antimicrobial Susceptibility Profile of Bacteria among Pregnant Women Attending Saint Paul's Hospital Millennium Medical College Addis Ababa Ethiopia. Therapeutics and Clinical Risk Management, 16, 923-932. https://doi.org/10.2147/TCRM.S267101

[55] Onyango, H.A., Ngugi, C., Maina, J. and Kiiru, J. (2018) Urinary Tract Infection among Pregnant Women at Pumwani Maternity Hospital Nairobi, Kenya: Bacterial Etiologic Agents, Antimicrobial Susceptibility Profiles and Associated Risk Factors. Advances in Microbiology, 8, 175-187. https://doi.org/10.4236/aim.2018.83012

[56] Gessese, Y.A., Damessa, D.L., Amare, M.M., Bahta, Y.H., Shifera, A.D., Tasew, F.S., et al. (2017) Urinary Pathogenic Bacterial Profile, Antibiogram of Isolates and Associated Risk Factors among Pregnant Women in Ambo Town, Central Ethiopia: A Cross-Sectional Study. Antimicrobial Resistance \& Infection Control, 6, 132. https://doi.org/10.1186/s13756-017-0289-6

[57] Mittal, S., Sharma, M. and Chaudhary, U. (2015) Biofilm and Multidrug Resistance in Uropathogenic Escherichia coli. Pathogens and Global Health, 109, 26-29. https://doi.org/10.1179/2047773215Y.0000000001 


\section{Appendix}

\section{Questionnaire}

Identification and antibiotic resistance profile of uropathogenic bacteria from sexually active women in Lagos, Nigeria

ID. No:

Name of Health Personnel (interviewer):

Health facility:

Interview starts: Interview ends: Date:

Please, circle the appropriate answer.

\section{Section A: Background of Respondents}

1. Age (last birthday):
2. Marital status:
(a) Single
(b) Married
(c) Divorced
(d) Separated
(e) Widowed

3. How many children do you have?
(a) None
(b) 1
(c) 2
(d) 3
(e) 4
(f) $>4$

4. Level of education: (a) None

(b) Primary

(c) Secondary

(d) Tertiary

5. Religion:

(a) Christianity (b) Islamic

(c) Traditional

(d) Others (specify).

6. Occupation:

(a) Trader

(b) Unemployed

(c) Civil servant

(d) Self- employed

(e) Retired

(f) Housewife

(g) Student

(h) Others (specify)

7. Which location do you live?

(a) Rural area

(b) Urban area

(c) Semi-urban area

8 . What is your estimated income monthly?
(a) $<$ N10,000
(b) N10,000 - N50,000
(c) N51,000 - N100,000
(d) N101,000 - N150,000
(e) N151,000 - N200,000
(f) N201,000 and above

\section{Section B: Reproductive History}

9. Have you been pregnant before?

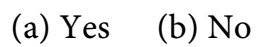

10. If your answer to Question 9 is yes, how many children have you given birth to alive?
(a) 1
(b) $>1$

11. What method did you use in delivering you children?
(a) Vaginal
(b) Operation
(c) Vaginal \& Operation

12. Has your pregnancy been terminated before (miscarriage or abortion)?
(a) Yes
(b) No

13. If your answer to Question 12 is yes, was the miscarriage or abortion
(a) induced
(b) spontaneous

14. Have you had still birth in your life time?
(a) Yes
(b) No

15. If your answer to Question 14 is yes, how many times?
(a) 1
(b) $>1$

16. Do you have history of family planning?
(a) Yes
(b) No
(c) Not applicable

17. If your answer to Question 16 is yes, what type of family planning are you using?
(a) Natural
(b) Barrier methods
(c) Injectables
(d) IUD 

(e) oral contraceptives
(f) spermicides
(g) Not applicable

18. Are you pregnant now?
(a) Yes
(b) No
(c) not sure

\section{Section C: Risk Behaviour}

19. What is the number of your lifetime sexual partners?
(a) 1
(b) 2 - 5
(c) $6-10$
(d) $>10$
(e) Don't remember

20. What was your age at first sexual activity
(a) less than 10 years
(b) 11 - 15 years
(c) 16 - 20 years
(d) $21-25$ years
(e) 26 - 30 years
(f) $>30$ years

\section{Section D: Symptoms (From Case Record Form)}
21. (a) vaginal itching
(b) lower abdominal pain
(c) rash
(d) pelvic pain
(e) genital blisters or ulcers
(f) discharge
(g) small boils around the vagina
(h) foul odour from vagina
(i) painful urination
(j) others (specify) 